\section{参考 文 献}

1) J.H. Dudus, F: R. Collins : Weld. J., 45-6 (1966), 241s249s.

2) G. L. Petrov, A. G. Makarov : Auto. Weld., 14-9 (1961), 18-24.

3) F. G. Gibbs : Weld. J., 45-10 (1966), 445s-453s.

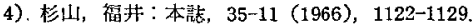

5) 杉以, 福井: 本誌, 36-11 (1967), 1194-1202,

6) 福井：整金属，18-6 (1968)，320-331.

7) 山本: 軽金属溶接, 71-11 (1968), 525-533

8) J.G. Young : Weld. J., 47-10 (1963), 451s-461s.

9) 因和，吉国：整金属，19-11 (1969)，470-480.

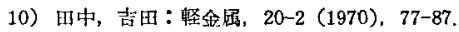

11）松田，中田，西尾，榢本，成㟲：本会諭文集, 4-1 (1986), 115-120。

12) D.C. Brown, F.A. Crossley, J.F. Rudy, H. Schwartzbart: Weld. J., 41-6 (1962), 241s.

13）柴田，浅井：本会請櫭，9(1971)，231-232,

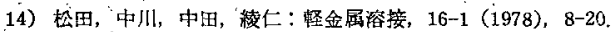

15) F. Matsudà, K. Nakata, Y. Miyanaga; M. Kayano, K. Tsukamoto: Trans. JWRI; 7-2 (1978), 181-193.

16) F. Matsuda, M. Ushio, H. Nakagawa, K. Nakata:
Proceedings of International Conference on Arc Physics and Weld Pool Behavior, The Welding Institute, Londion, 1979, 337-347.

17) V.P. Chernysh; V.A. Pakhareako: Auto. Weld., 32-5 (1979), 12-14.

18) B.P. Pearce, H. W. Kerr : Met. Trans. B, 12B-9 (1981), $479-486$.

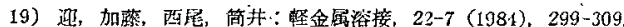

20）大施，若元，流明：本会馀交集，3-1 (1985)，117-123.

.21) F. Matsuda, K. Nakata, K. Tsukamoto, T. Uchiyama: Trans. JWRI, 13-1 (1984), 57-66.

22) W. J. Johnston, G. R. Kotler, S. O'Hara, H. V. Ashcom, W. A. Tiller: Trans. AIME, 233-10 (1965), 1856-1860.

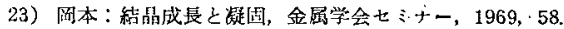

24）桃野，井川：軽金属，28-10 (1978)，499-505.

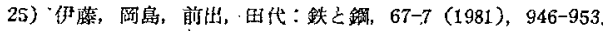

26）层谷川1，丸㛢，村中，星，衣笠：鉄と铜，67-8（1981），1354-1362，

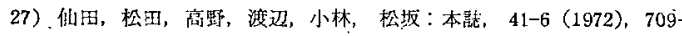
723.

28) Y. Arata, F. Matsuda, K. Nakata, K. Shinosaki : Trans. JWRI, 6-2 (1977), 207-212.

\title{
インバー材溶接金属の延性低下割れに及ぼす 金属学的因子の検討*
}

二 $\mathrm{Fe}-36 \% \mathrm{Ni}$. 合金溶接金属の延性低下割れ、関する研究（第 3 報）一

松田 福久**, 中川，博二***，張 月 嫦****

\begin{abstract}
Study on Metallurgical Factòrs Causing Ductility-dip Grack in Weld Metal of Invar*
\end{abstract}
-Ductility-dip Cracking in Weld Metal of Fe-36\% Ni Alloy (Report 3)-

by Fukuhisa Matsuda**, Hiroji Nakagawa*** and Yue-Chang Zhang*****

Mechanism of ductility-dip cracking in weld metal of Invar (Fe-36\% Ni alloy) reheated by following welding pass was studied from the viewpoints of grain boundary precipitation and grain boundary serration. Main conclusions obtained are as follows: ' (1) Temperature dependency of amount of precipitates on the fracture surface has good correlation with the characteristic of hot ductility. (2) The fracture surface of the specimen having low crack susceptibility has comparatively little amount of precipitates. (3) The features of intergranular fracture surface under different testing temperature and crosshead speed have intimate connection with that of grain boundary serration, and thus this suggests strongly that grain boundary serration has an important role on the ductility-dip crack. (4) Thus it is judged that both grain boundary precipitation and grain boundary serration cause cavity for nation cooperatively accompanied by grain' boundary sliding. (5) The mechanism of ductility-dip cracking was proposed synthetically from the viewpoints of grain boundary sliding, grain boundary serration, grain boundary precipitation, grain boundary migration, deformation stress and recrystallization.

Key Words: Weldability Tests, Hot Cracking, Controlled Expansion Alloys, Containers, Low Temperature, GTA Welding

\section{1. 緒霄}

第 1 報) 亿おいて, $\mathrm{Fe}-36 \% \mathrm{Ni}$ 合金（インバー）は， その溶接金属が次パス等によって再加熱を受けた場合に

\footnotetext{
*原稿受付 昭和60年 8 月 29日 昭和61年度香季全国大会論交発表請演

**正 員大服大学 Member, Osaka University

***.正 買 大阪大学 Member, Osaka University

****正資大阪大学 (上海交通大学) Member, Osaka Univ。 (Shanghai Jiao Tong University)
}

姃性低下割れが発生し易く，またこの割れの感受性は·S $\mathrm{N}, \mathrm{O}$ および Al 等の不純物量を低減させることにより 奏用上問題のない程度にまで軽減できることを示した。 さらに第 2 報2》において，上記の延性低下現象を再現高 温延性試験法に上り検討し，その結果，800 900 ${ }^{\circ} \mathrm{C}$ 付近 において粒界すへりにより粒界に空洞が形成し，乙れが 成辰して割れ発生となるとと，また空洞の形成には粒界 析出物亡粒界波状化が関与している可能性を示した。し かしその発生機楅を詳細に解明するには到らなかった。 
そこで本報告ではこの点についてさらに明解にすること を試みた。

\section{2. 使用材料およひ実験方法}

\section{1 使用材料}

使用した 5 種類の試作 $\mathrm{Fe}-36 \% \mathrm{Ni}$ 合金の化学組成を Table 1 亿示す. 試片 No. 1, 9 および12は既報1,2)で用 いたものである. No. 1 は割れ難く, No. 9 と12は割れ 易い材料であった．試片 No. 25 および26は S および $\mathrm{Al}$ をそれぞれ単独に添加したあので，いずれあ割れ易い材 料である. 板厚は $3 \mathrm{~mm}$ である。

\section{2 再現高温延性試験}

破面，析出物および粒界の状態を詳しく検討するため に第 2 報2) と同様の再現高温延性試験を行なった。試片 形状は平行部が幅 $6 \times$ 厚さ $3 \mathrm{~mm}$ であり, 溶接金属は試 片の中央に位置していて溶接方向に直角に引張変形を与 えた．溶接は GTA (DCEN, 溶加材なし) とし，溶接 条件は $100 \sim 105 \mathrm{~A}, 11 \sim 13 \mathrm{~V}, 100 \mathrm{~mm} / \mathrm{min}$ である. 溶接時には試片裏面からあ $\mathrm{Ar}$ シールドを行なった。

高温延性試験は高周波誘導加熱方式による加熱途中で の引張りとした (Ar 雾团気). そのプログラムの詳細は 第 2 報2) で示したでとくであり, 試験温度は 500 1100 ${ }^{\circ} \mathrm{C}$ とた. 試験温度に到達後 3 秒保持してからクロス

Table 1 Chemical compositions of materials used

\begin{tabular}{|c|c|c|c|c|c|c|c|c|c|}
\hline \multirow{2}{*}{ Item No. } & \multicolumn{9}{|c|}{ Chemical composition (wt. ") } \\
\hline & c & 51 & $M_{n}$ & $P$ & s & N & $\circ$ & $\mathrm{Al}^{*}$. & N1 \\
\hline 1 & 0.031 & 0.20 & 0.50 & 0.002 & 0.0011 & 0.0008 & 0.0034 & 0.009 & 36.25 \\
\hline 9 & 0.017 & 0.19 & 0.36 & 0.001 & 0.005 & 0.0017 & 0.0036 & 0.001 & 36.20 \\
\hline 12 & 0.033 & 0.19 & 0.35 & 0.003 & 0.005 & 0.0035 & 0.0021 & 0.001 & 36.05 \\
\hline 25 & 0.009 & 0.21 & 0.33 & 0.003 & 0.0249 & 0.0015 & 0.0133 & 0.002 & 35.29 \\
\hline 26 & 0.013 & 0.25 & 0.34 & 0.001 & 0.0007 & 0.0016 & 0.0024 & 0.516 & 36.23 \\
\hline
\end{tabular}

ヘッド・スピード (C.H.S.) $\dot{d}_{h}(13.3 \mathrm{~mm} / \mathrm{sec}), \dot{d}_{m}(0.56$ $\mathrm{mm} / \mathrm{sec}$ ) で変形を与えた。延性は破断部における試 験 前後の試片幅の変化 $\left(\left(W-W^{\prime}\right) / W \times 100(\%) \equiv \Delta W / W \times\right.$ $100(\%)$, ここで $W$ : 元の幅 $(6 \mathrm{~mm}), W^{\prime}$ : 試験後の幅) により評価した。

破面上および研磨面上での析出物は SPEED 法源にて 電解処理を行なった後に SEM で観察した。 なお高温脆 性には粒界の析出物の数が重要な役割りを果すといわれ ている4). そこで本報告でも破面上の析出物の数を測定 したが，これには倍率 $\times 15,000 に て$ 任意の約10個所の破 面を観察し, EDX で確認しながら析出物数を測定して その密度（個数 $/ 100 \mu \mathrm{m}^{2}$ ) を評価した。

\section{3. 実験結果および考察}

\section{1 粒界析出之高温延性の関係}

延性低下割れの発生し易い試片 No. 12 における600, 900 および $1100^{\circ} \mathrm{C} て ゙ の$ 破面の析出物を Fig. 1 に示す. 延 性の極小を示した付近である（b） $900^{\circ} \mathrm{C}$ におる破面上 の析出物は，低温側で延性が上昇し始める (a) $600^{\circ} \mathrm{C}$ お よび高温側で延性が再度上昇し始める（c） $1100^{\circ} \mathrm{C}$ に比 してかなり多かった。

延性低下割れの発生し難い試片 No. 1, S および Al

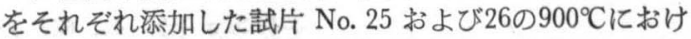
る破面上の析出物を Fig. 2(a)，(b) および (c) に示す. Fig. 2(a) の析出物は Fig. 1(b) に比してかなり少ない. 試片 No. 25 と26の高温延性は No. 12 より屯さらに低下 していたが，Fig. 2(b) および（c）に見られるように析 出物む多量に形成していた。

次に試片 No. 1 と12について破面上の析出物の密度を 測定した結果を Fig. 3 に示す.との図には延性 $\Delta W / W$ の測定結果も破線で併記した，密度の温度依存性は延性

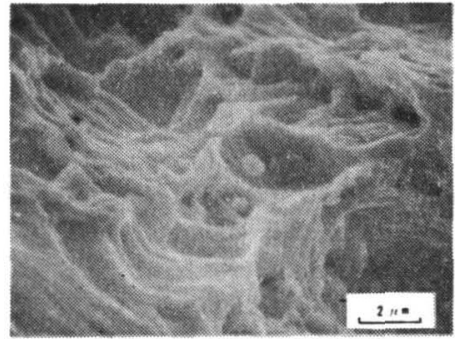

(a) $\mathrm{T}_{\mathrm{p}}: 600^{\circ} \mathrm{G}$

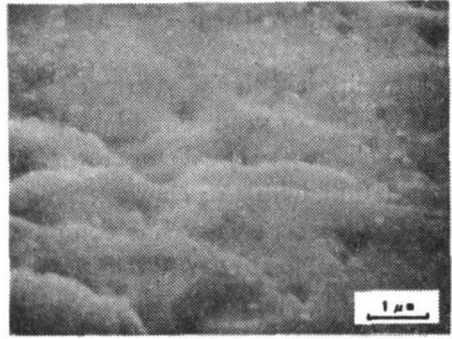

(b) $\mathrm{T}_{\mathrm{p}}: 900^{\circ} \mathrm{C}$

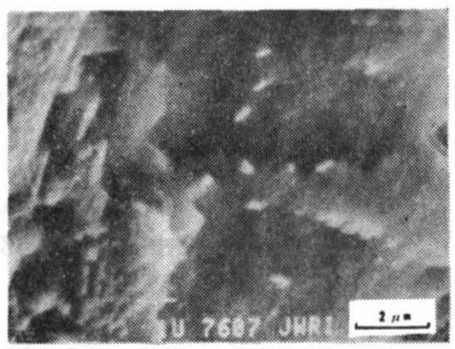

(c) $\mathrm{T}_{\mathrm{p}}: 1100^{\circ} \mathrm{G}$

Fig. 1 Precipitates on intergranular fractured surface under different testing temperature $\left(T_{p}\right)$, Material: Item No. 12, C.H.S.: $\dot{d}_{m}$

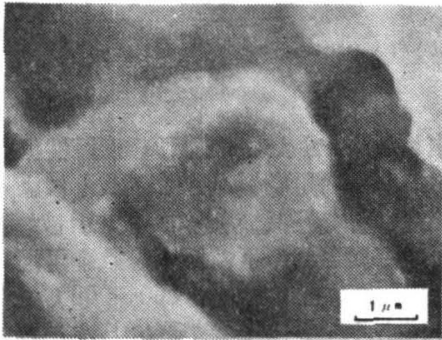

(a) Material: Item No. 1

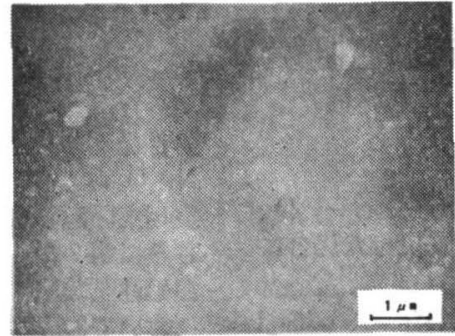

(b) Material: Item No. 25

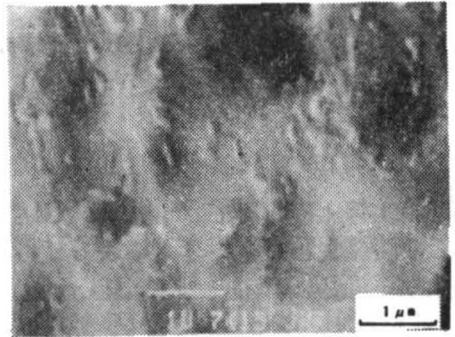

(c) Material: Item No. 26

Fig. 2 Precipitates on intergranular fractured surface of different materials, Testing temperature: $900^{\circ} \mathrm{C}$, C.H.S.: $\dot{d}_{m}$ 
の温度依存性とほぼ逆の関係にあり，延性が極小値とな る $800 \sim 900^{\circ} \mathrm{C}$ 付近で密度が最屯高い. また割れ易い材料 と割れ難い材料の密度の差屯明瞭に見られる.なお，さ らに実際に溶接割れ試験を行なって得られた破面につい ても検討を行なったが, 再現高温延性試験の場合と同様 に多数の析出物が観察された.

Fig. 4 は試片 No. 12 に対して $900^{\circ} \mathrm{C} て ゙$ 高温延性試験を 行なった後の研磨面での粒界の状態を示したものであ る.（a）は低倍率写真で, 中央縦方向に見られる移動粒 界は凝固時の粒界や樹枝状晶境界と交叉していないこと が分る．（b）は（a）の中央部付近を拡大したあので，粒 界上に微細な析出物が見られる。

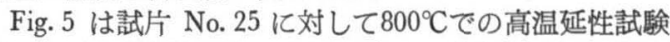
後の粒界の状態を示したあのである。（a）は低倍率写 真，(b) は（a）の中央の拡大および (c) は（a）の中央 やや左上方を拡大したあのである。（b) では粒界が樹枝 状晶境界とほとんど一致していたために凝固時に形成し た大きな介在物 (EDX により硫化物 $(\mathrm{MnS})$ と推定で きた）と共に微細な析出物としての硫化物が見られた. （c）では移動粒界は樹枝状晶境界と交叉していないため に微細な硫化物のみが見られた。なお析出物は粒界のみ ならず粒内であ見られた。

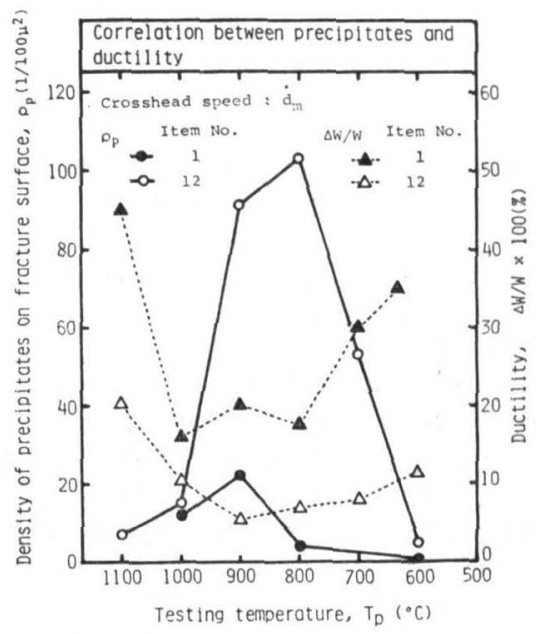

Fig. 3 Effect of testing temperature on density of precipitates on intergranular fractured surface, C.H.S.: $\dot{d}_{m}$
またなお破面は凹凸が激しいためにレプリカ作製が不 可能であったが, 研磨面上の析出物をレプリカ法により TEM で観察した結果によれば, $\mathrm{MnS}, \mathrm{MnO}, \mathrm{AlN}$ お よび $\mathrm{Al}_{2} \mathrm{O}_{3}$ が同定された。

\section{2 粒界波状化と高温延性の関係}

第 2 報2)で再現高温延性試験後には波状化した粒界が よく見られ，波状化粒界の周期にほほ対応して空洞が形 成しているととを述べた．このため粒界の波状化が延性 低下の一要因となっている可能性を示唆した、したがっ て，ここでは粒界波状化と高温延性に関して検討を行な った.

Fig. 6 は試片 No. 12 に対する高温延性試験後の粒界

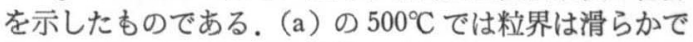
ある．（b）の $900^{\circ} \mathrm{C}$ では粒界は顕著に細かく波状化して

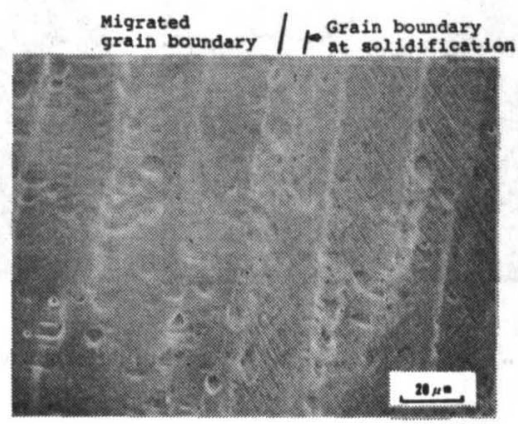

(a) low magnification

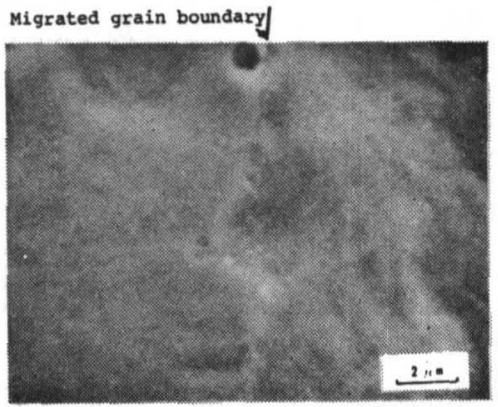

(b) high magnification

Fig. 4 Precipitates along grain boundary on polished and etched surface of Item No. 12 fractured at $900^{\circ}$ C, C.H.S.: $\dot{d}_{m}$

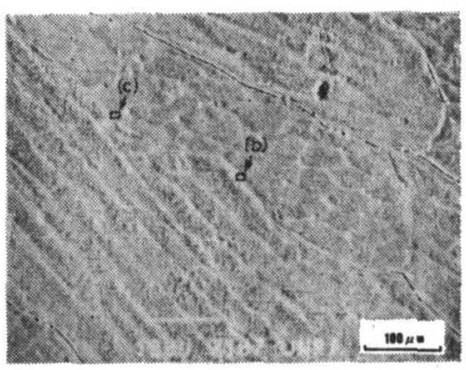

(a) low magnification

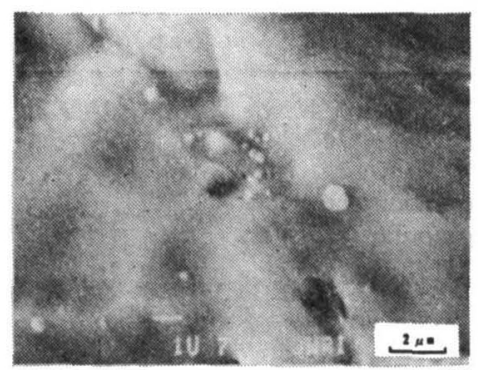

(b) high magnification

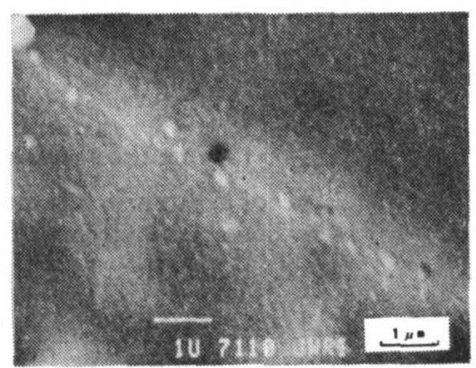

(c) high magnification

Fig. 5 Precipitates along grain boundary on polished and etched surface of Item No. 25 fractured at $900^{\circ} \mathrm{C}$, C.H.S.: $\dot{\mathrm{d}}_{\mathrm{m}}$ 


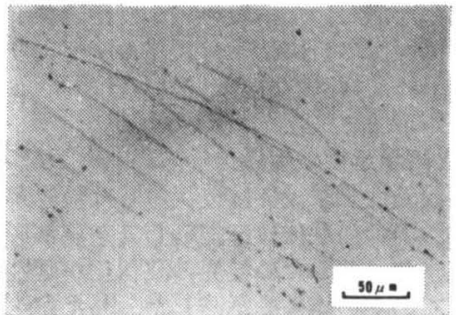

(a) $\mathrm{T}_{\mathrm{p}}: 500^{\circ} \mathrm{C}$

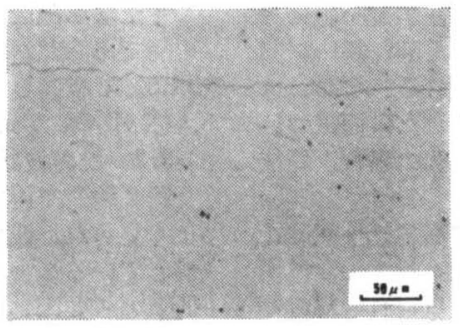

(b) $\mathrm{T}_{\mathrm{p}}: 900^{\circ} \mathrm{C}$

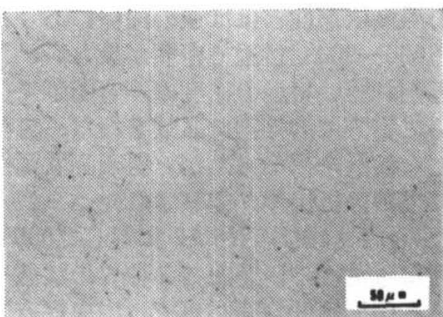

(c) $\mathrm{T}_{\mathrm{p}}: 1100^{\circ} \mathrm{C}$

Fig. 6 Grain boundary serration under different testing temperature $\left(T_{p}\right)$, Item No. 12, C.H.S.: $\dot{d}_{m}$

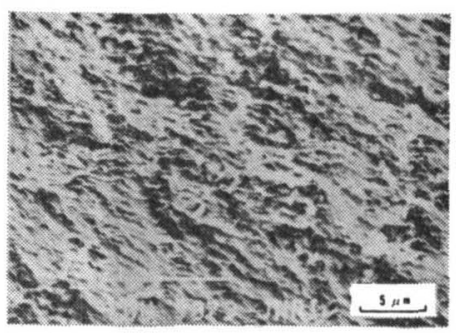

(a) $\mathrm{T}_{\mathrm{p}}: 600^{\circ} \mathrm{C}$

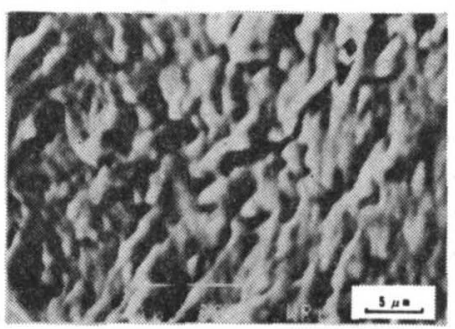

(b) $\mathrm{T}_{\mathrm{p}}: 900^{\circ} \mathrm{C}$

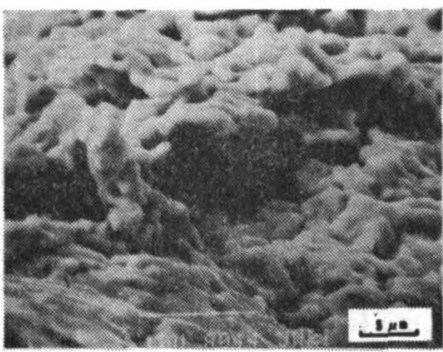

(c) $\mathrm{T}_{\mathrm{p}}: 1100^{\circ} \mathrm{C}$

Fig. 7 Feature of intergranular fractured surface under different testing temperature $\left(T_{p}\right)$, Item No. 12 , C.H.S.: $\dot{d}_{m}$

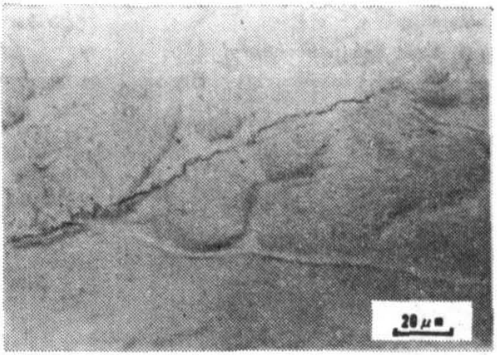

(a) grain boundary

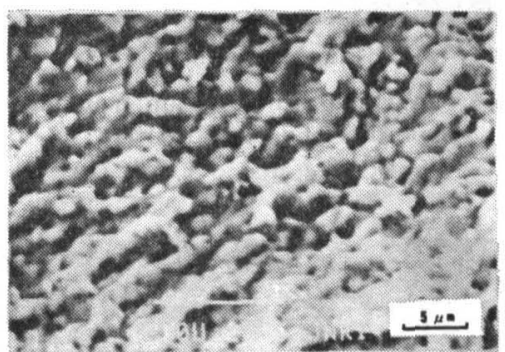

(b) fractured surface

Fig. 8 Effect of high strain rate on grain boundary serration and feature of intergranular fractured surface, Item No. 12, C.H.S.: $d_{m}$

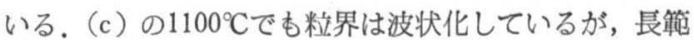
囲の粓界移動の影響によると思われる波長の増加が見ら れる.これらに対応する破面を Fig. 7 に示す. いずれむ 粒界破面は第 2 報2)で述へたように凹凸の特徽 (Type C) を示しているが, (a) の $600^{\circ} \mathrm{C}$ でその凹凸の寸法は

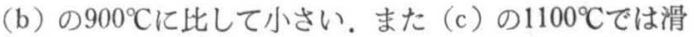
らかな階段状の部分が増加し, 全体的な山凸が（b）に 比して粗くなっている. また Fig. 8 は試片 No. 12 亿対 して $900{ }^{\circ}$ Cで C.H.S. を和としたときの粒界と破面を示 しており，Fig. 6(b) および 7(b) に比して粓界および破 面のいずれも山凸がやや紐かくなっている. さらに Fig.

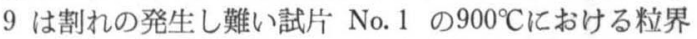
と破面を示したあのであり, 析出物はすでに述べたよう に少ないにあかかわらず，粒界の波状化および破面の山 凸の特幑は Fig. 6 および Fig. 7 とほぼ同様であった. また試片 No. 12 に対して割れの発生直後に変形を停止 させた場合であ粒界は波状化していた。

上記のように破面の凹凸の特徵が粒界と対応している ことは, 粒界の波状化が延性低下の重要な要因になって いることを示している.

従来，粒界すへりによる応力集中によって空洞が形成 する場所としては粒界上の析出物, 結晶変形等によって 生じた段 (ledge), 亚粒界との交点で粒界に生じたカスプ (cusp) 等がよく知られている.乙れらの中で粒界の段 やカスプが顕著になったあのが波状化粒界であり, Mul-

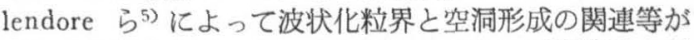
詳しく検討されている. また最近堀内ら ${ }^{6)}$ は析出物の存 在しない $\mathrm{Al}-\mathrm{Mg}$ 合金の高温延性試験において粒界が波 状化することにより空洞が形成して延性が低下するとと を示した。 そして, 堀内ら ${ }^{6)}$ は Raj と Ashby7) による 粒界すへり時の応力解析式を用いて波状化粒界での応力 集中係数が約 $2.5 \sim 5.0$ に達するととを示し, さらにこの 值は空洞形成時に必要な応力集中係数以上であることを 示した。すずに Fig. 6(b) で示したインバー溶接金属の 波状化粒界の波長および振幅などは堀内 ら ${ }^{6)}$ の $\mathrm{Al}-\mathrm{Mg}$ 合金での波状化粒界とほぼ同様であり，このことよりイ 


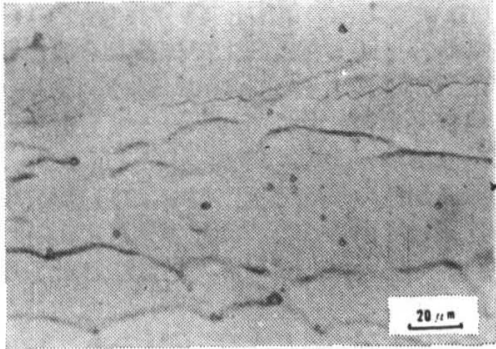

(a) grain boundary $\left(\mathrm{T}_{\mathrm{p}}: 900^{\circ} \mathrm{C}\right)$

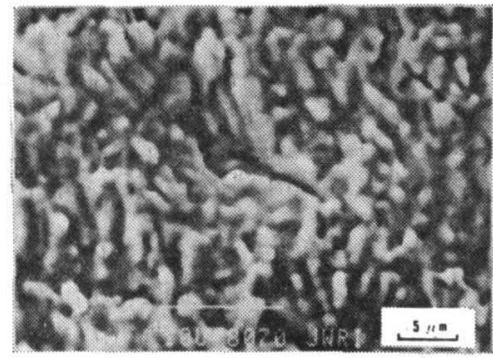

(b) fractured surface $\left(\mathrm{T}_{\mathrm{p}}: 800^{\circ} \mathrm{C}\right)$

Fig. 9 Grain boundary serration and intergranular fractured surface of Item No. 1 which has low crack susceptibility, C.H.S.: $\dot{d}_{m}$

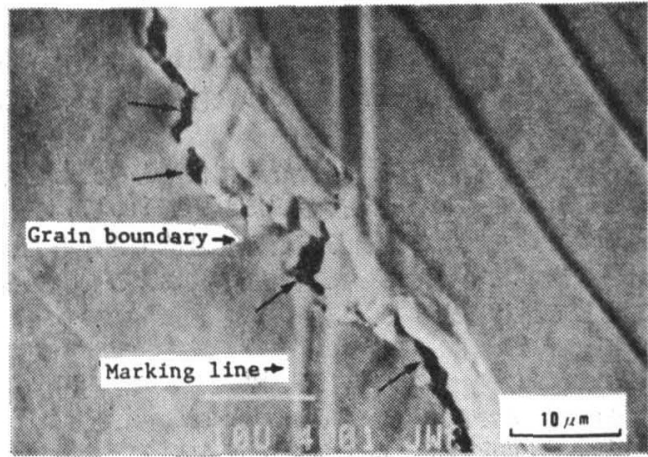

Fig. 10 An example of grain boundary sliding accompanying grain boundary migration, grain boundary serration and cavity formation, Item No. $12, \mathrm{~T}_{\mathrm{p}}: 800^{\circ} \mathrm{C}$, C.H.S.: $\dot{\mathrm{d}}_{\mathrm{m}}$

ンパー溶接金属においてあ空洞形成に必要な応力集中が 生じているあのと考えられる.

これらのことからインバー溶接金属においても粒界波 状化は延性低下を引き起こす一要因となっていることが

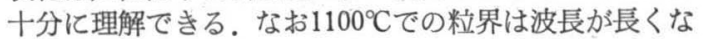
る傾问が見られたが，これはいわゆる通常の粒界移動の 効果が影響したためと考えられ，そのため粒界への丕集 中が緩和されて空洞が形成し難く延性を上昇させたもの と考えられる.

粒界波状化の機構についてはいくつか提案がなされて いるが5,8-10)，まだ十分解明されていない. すでに Fig.

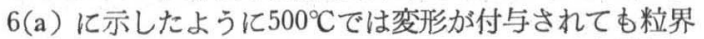
は波状化しなかった。 また単に熱サイクルのみを付与し て変形が付与されない場合にも粒界は波状化しなかっ た.とのととは,すでに一, 二指摘されてきたよう

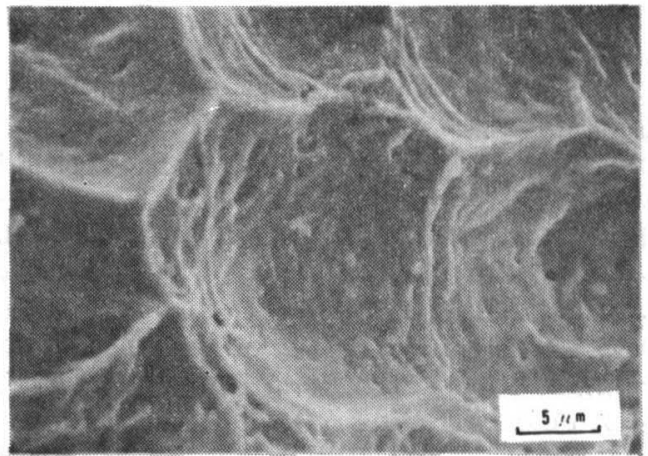

Fig. 11 An example of existence of two or more precipitates in intergranular dimple, Item No. $12, \mathrm{~T}_{\mathrm{p}}: 900^{\circ} \mathrm{C}$, C.H.S. : $\dot{\mathrm{d}}_{\mathrm{m}}$

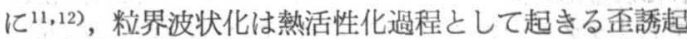
粒界移動であることを示唆している。また粒界波状化は 粒界すべりの動的過程と関係があるととも指摘されてい るが5)，本研究であそのととが観察された。すなわち Fig. 10 は試片表面における粒界波状化と空洞形成を示 したあのであるが (空洞 : 矢印で表示)，粒界移動の痕 跡と共に粒界すへりがよく見られる。

3.3 延性低下割れの発生に及ぼす粒界析出と粒 界 波 状化の影響についての比較考察

以上述べたように粒界析出物抒よび粒界波状化は共に 延性低下を引き起としているむのと考えられた，以下で はてれらについて比較考察を加えた。

従来, 高温延性等の研究において破面上に析出物が見 られた場合，乙れが延性低下の原因と考えられることが 多い. しかし $\mathrm{Raj}^{13)}$ は内部酸化により $\mathrm{SiO}_{2}$ 粒子を含ま せた銅の高温破壊において，破面上に $\mathrm{SiO}_{2}$ 粒子が見ら れてもその間隔が空洞の間隔と一致しない場合には空洞 はその粒子で形成したあのではないことを示した.イン バー溶接金属においては前報 ${ }^{2}$ の Fig. 15 で示したよう に波状化粒界の波長にほぼ相当して空洞が形成してい た. またすでに Fig. 6〜9 で示したように粒界の凹凸の 特徴屯波状化粒界亡の関連が強い，いっ法う延性低下の 大きい試片 No. 12 では破面上の析出物の平均間隔は一 般的に破面の凹凸の大きさより小さい。 また試片 No.12 において時折見られる粒界 dimple を Fig. 11 に示すが, 一つの空洞に相当すると思われる dimple 内に複数の析 出物が見られる. また不純物元素の極めて少ない試片 No. 1 においても Fig. 3 に示したように $600 \sim 1000^{\circ} \mathrm{C} の$ 間で延性低下がかなり起きていることから粒界波状化の 影響がよく理解できる。

$\mathrm{Raj}^{13}$ )によれば，高温粒界破壊の機構は低応力時の拡 散支配型空洞成長之高応力時の望性変形支配型空洞成長 に大別できるが，応力がさらに高くなる之粒界での粒内 すべりの不適合によって粒界破壊が生じ，乙の場合の破 面にはすべり帯が多数見られて破断時間は $30 \mathrm{sec}$ 程度 と非常に短い. インバー溶接金属においても第 2 報 ${ }^{2)}$ の Fig. 13 に示したように破面上ですべり帯が見られるこ とが多く，またすべり帯の形成が粒界波状化と関連があ る可能性を指摘した. 溶接時の延性低下割れは溶接熱音 イクル時の短時間で生じるあのであるから，てれらのと とがらあ粒界波状化の重要性を示唆するものと考えられ 
る.なお奏際に自拘束式溶接割机試験を行なった場合に あ粒界波状化が認められた ${ }^{14)}$.

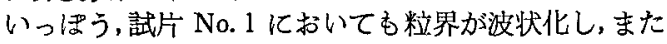
破面の特徴む同㥞であるにあかかわらず，延性低下の程 度が試片 No.12 はどには大きくないととは, 粒界析出 物む延性低下の重嫯な团子であることを示している.ま た前報2において示したように延性の極小温度は C.H. S. にあまり依存しないが，てのと亡屯堀内ら ${ }^{15)}$ の指摘 のように粒界析出物の影響力無視できないととを示唆し ていると考えられる。これらのととを総合すると，イン バー溶接金属においては粒界析出之波状化粒界の共同效 果によって延性低下が起きるあのと考えられる。

したがって次のような機構か推測される。まず粒界す べり時に粒界波状化によってその波長に相当するように 応力集中の分布が生ずる. 全体的な応力分布はこれに よって決定されると考えられるが, 析出物の部分ではこ れによる応力集中が重畳されるかまたはさらに析出物と マトリックスの界面が剝離し易いために，波状化粒界に おりる析出物の位置で空洞が発生し易い。したがって析 出物が少ない場合は波状化粒界による忘力集中があって あ空洞が発生し難い．そして一旦空洞が形成すると，そ の成長合体によって割れに進展する。

\section{4 延性低下割れに関係する諸因子の総合的評価}

第 2 報2) と本報告で明らかになったととがらをすとに して，インバー溶接金属に括いて延性低下劃机関係す る諸因子を Fig. 12 に総合的に示した. $800 \sim 900^{\circ} \mathrm{C}$ 付近 で延性の極小の見られる延性低下現象（g）は粒界す心゙ り（a）ならびに粒界析出（b）之粒界波状化 (c) の共同 効果によって空洞加形成するてとにより生ずる. $600^{\circ} \mathrm{C}$ 以下では粒界すべりが起き難いのみならず粒界析出物す 少なく粒界も波状化し難いために延性は上昇する。 また $1100^{\circ} \mathrm{C}$ 付近以上では粒界移動（d）が活発になり，変形 応力（e）あ低下するために空洞が発生し難く，また波 状化粒界の波長む長い。また粒界析出む少ない。なお再

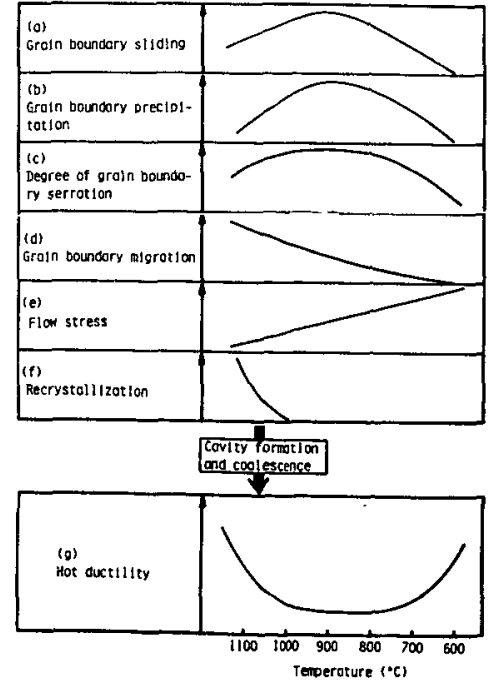

Fig. 12 Comprehensive illustration of mechanism causing ductility-dip cracking 結晶（f）によって丕の集中していた粒界そのものも消 堿し易くなる. $1100^{\circ} \mathrm{C}$ 付近以上ではこれらの影徨によっ て延性が上昇する。

なお不純物元素の粒界偏析はオージェ分析であとくに 見られなかったが，(i)Fig. 3 ならびに Fig. 6 および7で 示したように延性の傾向は析出物および粒界波状化の挙 動とよく対応していること，(ii)粒界偏析による粒界強度 の低下が原因であれば，C.H.S. を上昇ささるととによ り延性は低下すると考えられるが'16)，前報2)で示したよ うに延性は逆に上昇するとと等を考えても，粒界偏析の 影響は小さいと思われる。

\section{5. 結 言}

インバー溶接金属の延性低下割れに及ぼす各種金属学 的因子を検討した結果を要約すると次のとおりである.

1) 破面上の析出物量を湖定し, 試験温度との関連性 を検討した結果，延性低下の温度依存性は析出物量とよ い相関性がみられた。

2）一定温度にて延性低下の大きい試片と小さい試片 を比較した結果によれば前者の破面では析出物量汃明ら かに多かった。これらのととより粒界析出は延性低下の 重要な原因であると考えられる.

3）粒界の波状化之粒界破面の凹凸の特徴は密切に関 連していた。また粒界の波状化の温度依存性も延性の傾 向とよい相関性にあった。これらのととおよび他の文献 等の比較検討の結果, 粒界波状化も延性低下の重要な原 因であろうことを指摘した。

4）延性低下はしたがって粒界析出と粒界波状化の共 同効果によって空洞が形成し，その合体成長によって起 きるあのと荐えられた。

5）粒界すべり,粒界析出,粒界波状化, 粒界移動, 再結 晶等を総合してインバー溶接金属において $900^{\circ} \mathrm{C}$ 前後へ の再加熱で延性低下の起きる機構を総合的に考察した。

材料を提供していただいた川崎製鉄傲および日新製鋼 侏に記して謝意を表する。

\section{参 考 献}

1) 松田, 他：溶接学会䇶交集，3(1985)，p. 532 .

2) 松田, 他：溶接学会諭文集，3 (1985), p. 539 .

3）黑澤，他：金属学会会報，20（1981），p. 377.

4) 須藤：铁之銅，67 (1981), p. 696 .

5) A.W. Mullendore and N.J. Grant: "Structural processes in Creep". Iron and Steel Inst., 1961, f. 44.

6) 大塚, 堀内：金属学会誌, 48 (1984), p. 1143.

7) R. Raj and M.F. Ashby : Met. Trans,, 2 (1971), p. 1113.

8) B. Chalmers, et al. : "Progress in Materials Science", Pergamon press, 16 (1972), p. 19.

9) A.E.B. Presland and R. I. Hutchinson :J. Inst. Met., 92 (1963-64), p. 264.

10) F. Garofalo, et al. : Trans. Met. Soc. AIME, 230 (1964), p. 1460 :

11）日本金属学会編：“给属便婜”(呚訂服)，昭46，p，887.

12) F. Garofalo: "Fundamentals of Creep and Creep-Rupture in Metals", Macmillam Series in Materials Science, 1965, p. 144 .

13) R. Raj : Acta Met., 26 (1978), p. 341.

14) 末発表

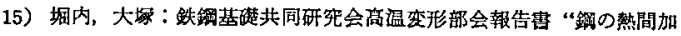
“工の金属学”, (昭57), p. 311 .

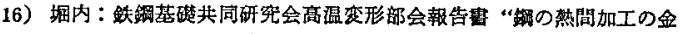
属学”, (昭57), p. 241. 